\title{
Faktor- Faktor yang Berhubungan dengan Upaya Pencegahan HIV/ AIDS pada Siswa Kelas X SMA Negeri 8 Banda Aceh Tahun 2016
}

\author{
Factors Relating to Efforts to Prevent HIVI AIDS in Class X Students of SMA \\ Negeri 8 Banda Aceh in 2016 \\ Asmaul Husna ${ }^{* 1}$, Munirah Dara Fonna \\ ${ }^{1,2}$ Program Studi D-III Kebidanan, Fakultas Ilmu Kesehatan, Universitas Ubudiyah Indonesia, Banda Aceh, Indonesia \\ *Korespondensi Penulis : asmaulhusna@uui.ac.id
}

\begin{abstract}
Abstrak
Menurut data Depkes (2012) dari bulan Januari hingga Desember tahun 2012, jumlah kasus HIV di Indonesia sebanyak 21.511 kasus dan AIDS sebanyak 5.686 kasus yang tersebar di 386 dari 498 kabupaten/kota di seluruh provinsi di Indonesia, dengan kasus terbanyak berasal dari Provinsi Papua.Menurut data komulatif kasus HIV/AIDS terbanyak pada usia 20-29 tahun sebanyak 45,4\% dan terendah pada usia 40-49 tahun sebanyak 9,9\%, dengan faktor risiko terbanyak adalah melalui heteroseksual. Tujuan dari penelitian ini untuk Untuk mengetahui faktor-faktor yang Faktor-faktor yang berhubungan dengan upaya pencegahan HIV/ AIDS Pada Siswa Kelas X SMA Negeri 8 Banda Aceh. Populasi dalam penelitian ini adalah seluruh siswa kelas X di SMA Negeri 8 Kota Banda Aceh yang berjumlah 244 yang terbagi dalam 8 kelas. Penelitian ini telah dilaksanakan pada tanggal 18 November sampai dengan 23 November Tahun 2016. Sampel adalah sebagian atau wakil dari polulasi yang diteliti. Sampel dalam penelitian ini adalah sampel total (total sampling) yaitu seluruh siswa di SMA kelas X di SMA Negei 8 Kota Banda Aceh sebanyak 244 siswa siswi. Hasil analisis bivariat Terdapat hubungan antara pengetahuan dengan upaya pencegahan HIV/ AIDS Pada Siswa SMA Negeri 8 Banda Aceh, diperoleh $p$-value $=0,008(\mathrm{p}<0,05)$, Terdapat hubungan antara informasi dengan upaya pencegahan HIV/ AIDS Pada Siswa SMA Negeri 8 Banda Aceh, diperoleh $p$-value $=0,007(\mathrm{p}<0,05)$. Kesimpulan yang di dapat dari penenelitian sebagai berikut terdapat hubungan antara pengetahuan dengan upaya pencegahan HIV/ AIDS Pada Siswa SMA Negeri 8 Banda Aceh, diperoleh $p$-value $=0,008(\mathrm{p}<0,05)$, Terdapat hubungan antara informasi dengan upaya pencegahan HIV/ AIDS Pada Siswa SMA Negeri 8 Banda Aceh, diperoleh $p$-value $=0,007(\mathrm{p}<0,05)$.
\end{abstract}

Kata Kunci : Pengetahuan, informasi

\section{Abstract}

According to MOH data (2012) from January to December 2012, the number of HIV cases in Indonesia was 21,511 cases and AIDS as many as 5,686 cases spread in 386 out of 498 districts / cities in all provinces in Indonesia, with the most cases coming from Papua Province. According to the most cumulative data on HIV / AIDS cases at the age of 20-29 years as many as $45.4 \%$ and the lowest at the age of 40-49 years as much as $9.9 \%$, with the most risk factors being heterosexual. The purpose of this study is to determine the factors that are factors related to HIV / AIDS prevention efforts in Class X students of SMA Negeri 8 
Banda Aceh. The population in this study were all students of class X in SMA Negeri 8 Kota Banda Aceh, amounting to 244 which were divided into 8 classes. This research was carried out on November 18 to November 23, 2016. Samples were in part or representative of the pollulations studied. The sample in this study was a total sample (total sampling) that is all students in class X high school in Negei 8 High School in Banda Aceh City as many as 244 female students. Bivariate analysis results There is a relationship between knowledge with HIV / AIDS prevention efforts in Banda Aceh State Senior High School 8 students, obtained pvalue $=0.008(p<0.05)$, There is a relationship between information with HIV / AIDS prevention efforts in Students of SMA 8 Banda Aceh, obtained $p$-value $=0.007$ ( $p<0.05)$. The conclusions obtained from the study are as follows: There is a relationship between knowledge with HIV / AIDS prevention efforts in Banda Aceh State Senior High School 8 students, obtained $p$-value $=0.008$ ( $p<0.05)$, There is a relationship between information with HIV / AIDS prevention efforts For students of Banda Aceh 8 High School, p-value = $0.007(p<0.05)$ was obtained.

Keywords: Knowledge, information

\section{PENDAHULUAN}

Syndrome imunodefiensi yang di dapat (AIDS =Acquired Immunodeficiency syndrome) adalah suatu penyakit infeksi yang disebabkan oleh retro virus yang dikenal dengan nama Human T-cell Iymphotropic Virus (HIV). Virus tersebut bisa ditularkan melalui hubungan seksual, jarum suntik yang tercemar, tranfusi darah atau bahan-bahan dari darah atau secara perinatal dari ibu kepada bayinya (Scorviani, 2012).

Menurut data Depkes (2012) dari bulan Januari hingga Desember tahun 2012, jumlah kasus HIV di Indonesia sebanyak 21.511 kasus dan AIDS sebanyak 5.686 kasus yang tersebar di 386 dari 498 kabupaten/kota di seluruh provinsi di Indonesia, dengan kasus terbanyak berasal dari Provinsi Papua.Menurut data komulatif kasus HIV/AIDS terbanyak pada usia 2029 tahun sebanyak 45,4\% dan terendah pada usia 40-49 tahun sebanyak 9,9\%, dengan faktor risiko terbanyak adalah melalui heteroseksual.

Berdasarkan data di SMA Negeri 8 Banda Aceh jumlah siswa kelas X keseluruhannya berjumlah 244 orang siswa, yang terdiri kelas $X^{1}$ IPA 25 siswa, $X^{2}$ IPA 30 siswa, $X^{3}$ IPA 28 siswa, $X^{4}$ IPA 32 siswa, $X^{5}$ IPA 27 siswa, $X^{6}$ IPS 34 siswa, $X^{7}$ IPS 34 siswa, $X^{8}$ IPA 34 siswa. Dari hasil survei wawancara dengan beberapa murid di SMA Negeri 8 Banda Aceh di temukan 5 dari 10 orang yang tidak mengerti tentang kesehatan reproduksi dan pencegahan HIV/ AIDS ( SMA Negeri 8 Banda Aceh, 2016). 


\section{METODE PENELITIAN}

Penelitian ini menggunakan jenis penelitian yang bersifat survey analitik dengan desain cross-sectional. Populasi dalam penelitian ini adalah seluruh siswa kelas X di SMA Negeri 8 Kota Banda Aceh yang berjumlah 244 yang terbagi dalam 8 kelas. Penelitian ini telah dilaksanakan pada tanggal 18 November sampai dengan 23 November Tahun 2016. Sampel adalah sebagian atau wakil dari polulasi yang diteliti. Sampel dalam penelitian ini adalah sampel total (total sampling) yaitu seluruh siswa di SMA kelas X di SMA Negei 8 Kota Banda Aceh sebanyak 244 siswa siswi. Analisis univariat bertujuan untuk menjelaskan atau mendeskripsikan karakteristik setiap variabel penelitian. Pada analisis univariat peneliti hanya melihat distribusi frekuensi dan persentase setiap variabel yang diteliti yaitu kejadian diare, pengetahuan dan sikap ibu. Analisis bivariat pada penelitian ini menggunakan uji statistik chi square, dengan batas kemaknaan $(\alpha=0,05)$ atau Confident Level $(\mathrm{CL})=95 \%$. Diolah dengan menggunakan komputerisasi. Untuk analisa bivariat pada penelitian ini adalah melihat hubungan antara pengetahuan, informasi terhadap HIV/AIDS. Nilai yang dilihat untuk mengetahui kedua variabel ada hubungan adalah dengan nilai $\mathrm{p}<0,05$.

\section{HASIL PENELITIAN}

Tabel 1. Hubungan Pengetahuan dengan Upaya Pencegahan HIV/ AIDS pada Siswa SMA Negeri 8 Banda Aceh

\begin{tabular}{llccccccc}
\hline No & Pengetahuan & \multicolumn{3}{c}{$\begin{array}{c}\text { Upaya pencengahan } \\
\text { HIV/AIDS }\end{array}$} & & Total & \multirow{2}{*}{ P Value } \\
\cline { 3 - 7 } & & \multicolumn{3}{c}{ Tinggi } & \multicolumn{2}{c}{ Rendah } & & \\
\cline { 2 - 7 } & & f & \% & f & \% & n & \% & \\
\hline 1 & Baik & 86 & 61,9 & 53 & 38,1 & 139 & 100 & 0,008 \\
2 & kurang & 46 & 43,8 & 59 & 56,2 & 105 & 100 & \\
\hline
\end{tabular}

Tabel 2. Hubungan Informasi dengan Upaya Pencegahan HIV/ AIDS pada Siswa SMA Negeri 8 Banda Aceh

\begin{tabular}{|c|c|c|c|c|c|c|c|c|}
\hline \multirow[t]{3}{*}{ No } & \multirow[t]{3}{*}{ Informasi } & \multicolumn{4}{|c|}{$\begin{array}{c}\text { Upaya pencengahan } \\
\text { HIV/AIDS }\end{array}$} & \multirow{2}{*}{\multicolumn{2}{|c|}{ Total }} & \multirow[t]{3}{*}{$P$ Value } \\
\hline & & \multicolumn{2}{|c|}{ Tinggi } & \multicolumn{2}{|c|}{ Rendah } & & & \\
\hline & & $\mathbf{f}$ & $\%$ & $\mathbf{f}$ & $\%$ & $\mathbf{n}$ & $\%$ & \\
\hline 1 & Pernah & 84 & 62,2 & 51 & 37,8 & 135 & 100 & 0,007 \\
\hline 2 & Tidak Pernah & 48 & 44 & 61 & 56 & 109 & 100 & \\
\hline
\end{tabular}




\section{Pembahasan}

1. Hubungan Pengetahuan Dengan Kejadian Diare Pada Balita

Berdasarkan hasil penelitian yang telah dilakukan oleh peneliti menunjukkan bahwa dari 139 responden upaya pencengahan HIVAIDS tinggi memiliki berpengetahuan baik sebanyak 86 responden (61,9\%). Dan dari 105 upaya pencengahan HIVAIDS tinggi memiliki berpengetahuan kurang baik sebanyak 46 responden $(43,8 \%)$. Setelah dilakukan uji statistik (Chi Square) diperoleh p-value $=0,008(\mathrm{p}<0,05)$. Maka dapat di simpulkan bahwa terdapat hubungan antara pengetahuan dengan upaya pencegahan HIV/ AIDS Pada Siswa SMA Negeri 8 Banda Aceh.

Berdasarkan penelitian oleh Tari (2012), menunjukkan bahwa dari 29 (43,3\%) responden yang pengetahuan tinggi, terdapat 20 responden $(29,9 \%)$ yang pencegahan HIV/AIDS juga tinggi. Sedangkan dari 38 responden yang pengetahuan rendah, terdapat 14 responden $(20,9 \%)$ yang pencegahan HIV/AIDS tinggi. Hasil analisis statistik menggunakan chi square menunjukkan hubungan tersebut bermakna dengan $\alpha=0,05 \leq p$ Value $=0,018$ dari hal tersebut menunjukkan bahwa ada hubungan antara pengetahuan dengan pencegahan HIV/AIDS.

Menurut pengetahuan adalah hasil tahu dan ini terjadi setelah orang melakukan pengindraan terhadap suatu objek tertentu. Pengideraan terjadi melalui panca indra manusia yakni indera penglihatan, pendengaran, penciuman, rasa dan raba. Sebagian besar pengetahuan manusia di peroleh dari mata dan telinga (Notoatmodjo, 2007).

Pengetahuan adalah segala hasil tanggap manusia (rasio dan indra) terhadap reharitas (Bogon dan Suyanto, 2006). Pengetahuan suatu involusi yang diketahui oleh para konsumen, tetapi mereka memiliki pengetahuan rendah dan perilaku kureang mendukung terhadap involusi / gagasan atau ide-ide (Rustam,2010).

\section{Hubungan Media Informasi Dengan Upaya Pencegahan HIV/ AIDS}

Berdasarkan hasil penelitian yang telah dilakukan oleh peneliti menunjukkan bahwa dari 135 responden upaya pencengahan HIVAIDS tinggi pernah mendapat informasi sebanyak 84 responden (62,2\%). Dan dari 109 upaya pencengahan HIVAIDS tinggi tidak pernah mendapat informasi sebanyak 48 responden (44\%). Setelah dilakukan uji statistik (Chi Square) diperoleh $p$-value $=0,007$ ( $\mathrm{p}<0,05)$. Maka dapat di simpulkan 
bahwa terdapat hubungan antara informasi dengan upaya pencegahan HIV/ AIDS Pada Siswa SMA Negeri 8 Banda Aceh.

Sumber informasi adalah keterangan pemberitahuan kabar berita tentang suatu media dan alat (sarana) komunikasi seperti koran, majalah, radio, televisi, poster, spanduk dan internet. Media komunikasi adalah media yang digunakan pembaca untuk mendapatkan informasi sesuatu atau hal tentang pengetahuan. Berkaitan dengan penyediaan informasi bagi manajemen dalam pengambilan keputusan, informasi yang diperoleh harus berkualitas (Sunaryo, 2004).

Informasi yang diperoleh baik dari pendidikan formal maupun non formal dapat memberikan pengaruh jangka pendek (immediate impact) sehingga menghasilkan perubahan atau peningkatan pengetahuan. Majunya teknologi akan tersedia bermacammacam media massa yang dapat mempengaruhi pengetahuan masyarakat tentang inovasi baru. Sebagai sarana komunikasi, berbagai bentuk media massa seperti televisi, radio, surat kabar, majalah, penyuluhan dan lain-lain mempunyai pengaruh besar terhadap pembentukan opini dan kepercayaan orang. Dalam penyampaian informasi sebagai tugas pokoknya, media massa membawa pula pesan-pesan yang berisi sugesti yang dapat mengarahkan opini seseorang. Adanya informasi baru mengenai sesuatu hal memberikan landasan kognitif baru bagi terbentuknya pengetahuan terhadap hal tersebut. (Notoadmodjo, 2007).

Menurut Notoatmodjo (2005), sumber informasi mempengaruhi pengetahuan baik dan media maupun orang-orang dalam terkaitnya dengan kelompok manusia memberi kemungkinan untuk dipengaruhi dan mempengaruhi anggota-anggota. Seseorang di dalam proses pendidikan juga memperoleh pengetahuan melalui berbagai macam alat bantu. Alat bantu media akan membantu dalam melakukan penyuluhan, agar pesan kesehatan dapat lebih mengerti fakta kesehatan dapat disampaikan dengan jelas. Dengan media orang dapat lebih mengerti fakta kesehatan yang dianggap rumit sehingga mereka dapat menghargai betapa bernilainya kesehatan.

Berdasarkan hasil penelitian yang telah dilakukan maka penelitian dapat mengumpulkan hasil dari penenelitian sebagai berikut Terdapat hubungan antara pengetahuan dengan upaya pencegahan HIV/ AIDS Pada Siswa SMA Negeri 8 Banda Aceh, diperoleh $p$-value $=0,008(\mathrm{p}<0,05)$, Terdapat hubungan antara informasi dengan 
upaya pencegahan HIV/ AIDS Pada Siswa SMA Negeri 8 Banda Aceh, diperoleh $p$-value $=0,007(\mathrm{p}<0,05)$.

\section{KESIMPULAN}

Terdapat hubungan antara pengetahuan dengan upaya pencegahan HIV/ AIDS Pada Siswa SMA Negeri 8 Banda Aceh, diperoleh $p$-value $=0,008(\mathrm{p}<0,05)$ dan terdapat hubungan antara informasi dengan upaya pencegahan HIV/ AIDS Pada Siswa SMA Negeri 8 Banda Aceh, diperoleh $p$-value $=0,007(\mathrm{p}<0,05)$.

\section{SARAN}

Diharapkan dapat menambah pengetahuan dan pengalaman dalam melaksanakan penelitian, tentang hubungan pengetahuan siswa SMA Negeri 8 Banda Aceh dengan kesehatan reproduksi dalam upaya pencegahan HIV/ AIDS TAHUN 2016.

\section{DAFTAR PUSTAKA}

Al-ghifari. 2010.Remaja Korban Mode. Mujahid Press : Bandung

Aisyaroh, N. 2011. Perilaku Perawatan Kepada Penderita HIV. Kotamadya Jakarta : Jakarta

Azwar, 2011. Pusat Promosi Kesehatan (Sehat dan Positif Untuk ODHA). Mujahid Press : Bandung

BKKBN, (2007). Pendewasaan Usia Perkawinan dan Hak-Hak Reproduksi Bagi Remaja Indonesia. Deputi Bidang Keluarga Berencana dan KesehatanRerpoduksi : BKKBN. Jakarta

Duarsa, Budi Susila. 2010. Informasi Kesehatan masyarakat. Esensi : Jakarta

Dhita, 2009. Epidemiologi, Penularan, Pencegahan, dan Pemberantasannya. Nuha Medika. Yogyakarta

Fatmah. 2010. Hubungan antara Pengetahuan dan Sikap Seksual Pranikah. Nuha Medika : Yogyakarta

Gordon B Davis (2007). Kerangka Dasar Sistem Informasi Manajemen Bagian I: Pengantar. Diterjemahkan oleh Andreas S. Adiwardana.Cetakan ke sebelas. PT. Ikrar Mandiri Abadi.

Handayani. 2011. Hubungan Pengetahuan Dan Sikap Tentang HIV/AIDS pada siswa SMK 3 Dengan Praktik Pencegahan. Program D-IV Kebidanan Fakultas Kedokteran Universitas Sebelas Maret Surakarta.

Hidayat. A. 2007. Metode Penelitian Keperawatan dan Tekhnik Analisa Data Jakarta: SalembaMedika 